\title{
Benitoite and Blueschist: Keeping up with Jo Laird
}

Mark Van Baalen, Harvard University

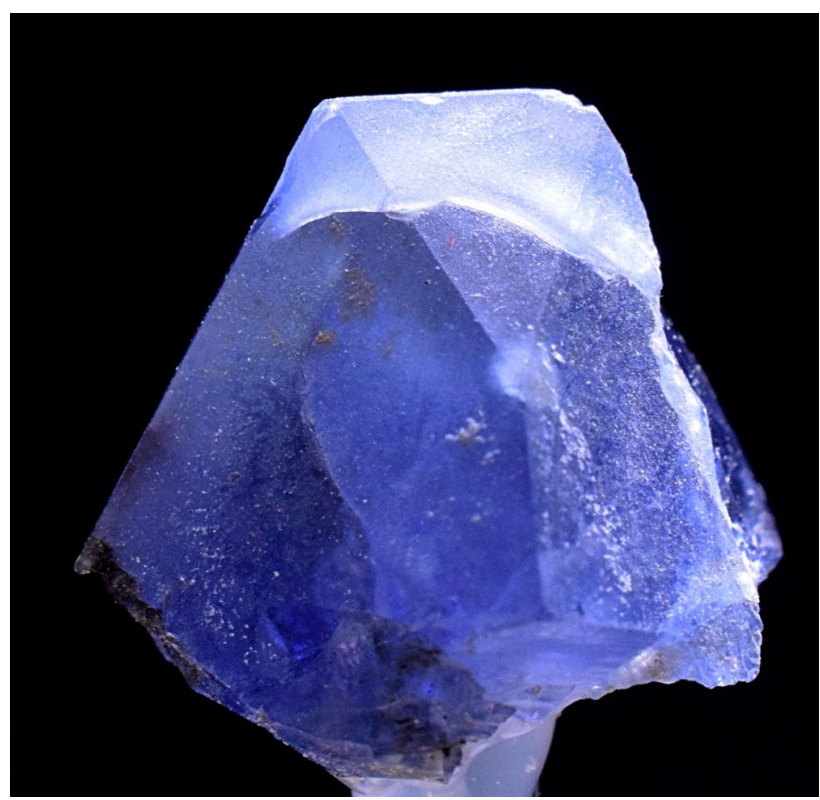

American Mineralogist

Vol. 57, pp. $85-102(1972)$

CHEMICAL COMPOSITION AND PHYSICAL, OPTICAL, AND STRUCTURAL PROPERTIES OF BENITOITE, NEPTUNITE, AND JOAQUINITE ${ }^{1}$

Jo Laird and Arden L. Albee, Division of Geological and Planetary Sciences, California Institute of Technology

Pasadena, California 91109 


\section{Benitoite}

- Rare blue gemstone

- Only known example of ditrigonaldipyramidal symmetry class $6_{\text {bar }} \mathrm{m} 2$

- Louderback \& Blasdale, 1909

- $\mathrm{BaTiSi}_{3} \mathrm{O}_{9}$

- Wet chemistry $\rightarrow$ microprobe

- Fluorescent in UV light

- New Idria Serpentinite

- Origin unclear: whither Ba, Ti?
Uw. Madison Geology $m$

\section{Electron Microprobe - 7}

-1960: ARL EMX, and MAC EMPs. 1961, first JEOL EMP. Many researchers build "homebrew" electron microprobes

- Motivation: space/arms race, semi-conductor and other materials research.

David Wittry built an EMP at Cal

Tech, shown to right (Thesis, 1957) He also translated Castaing's thesis. 


\section{Benitoite optical properties}

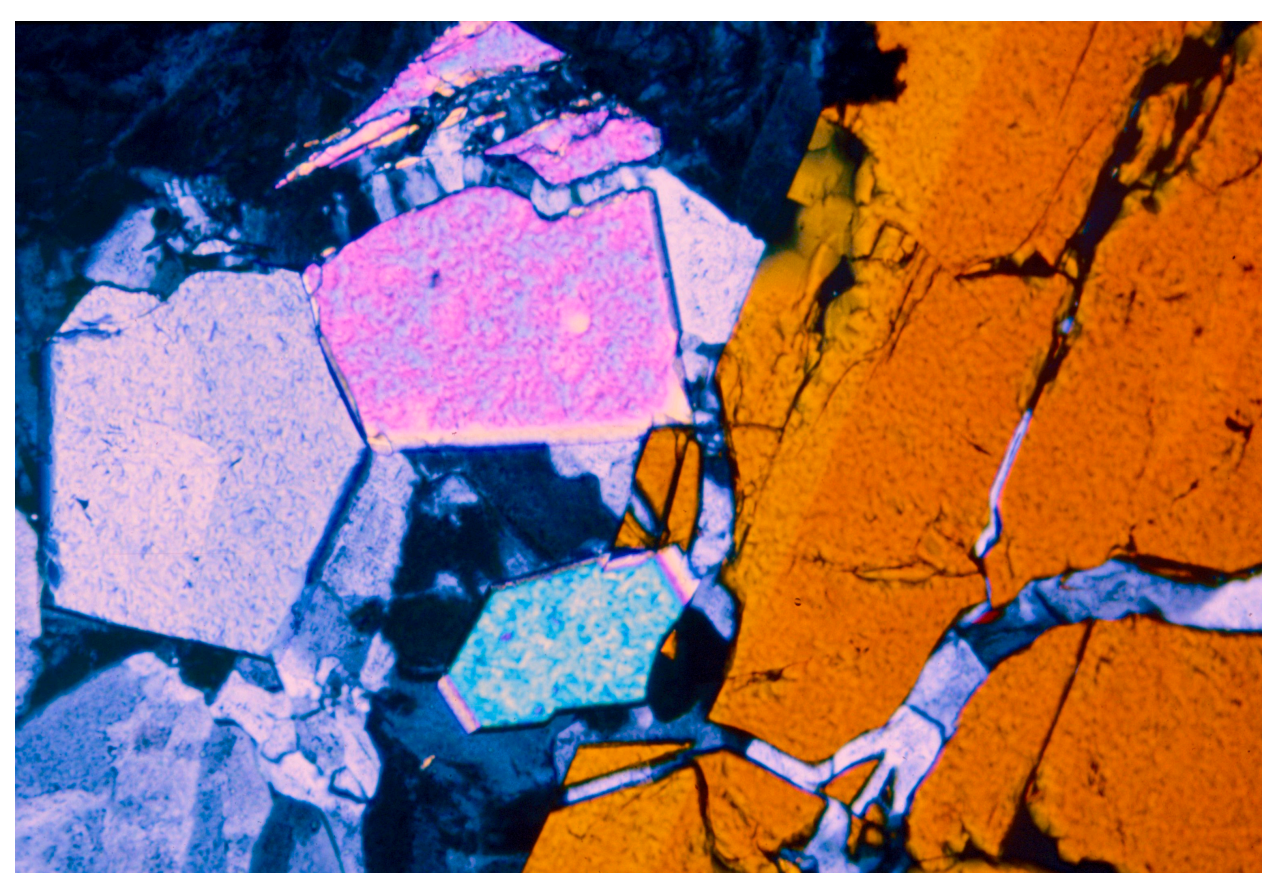

Benitoite with neptunite - field of view $5 \mathrm{~mm}$

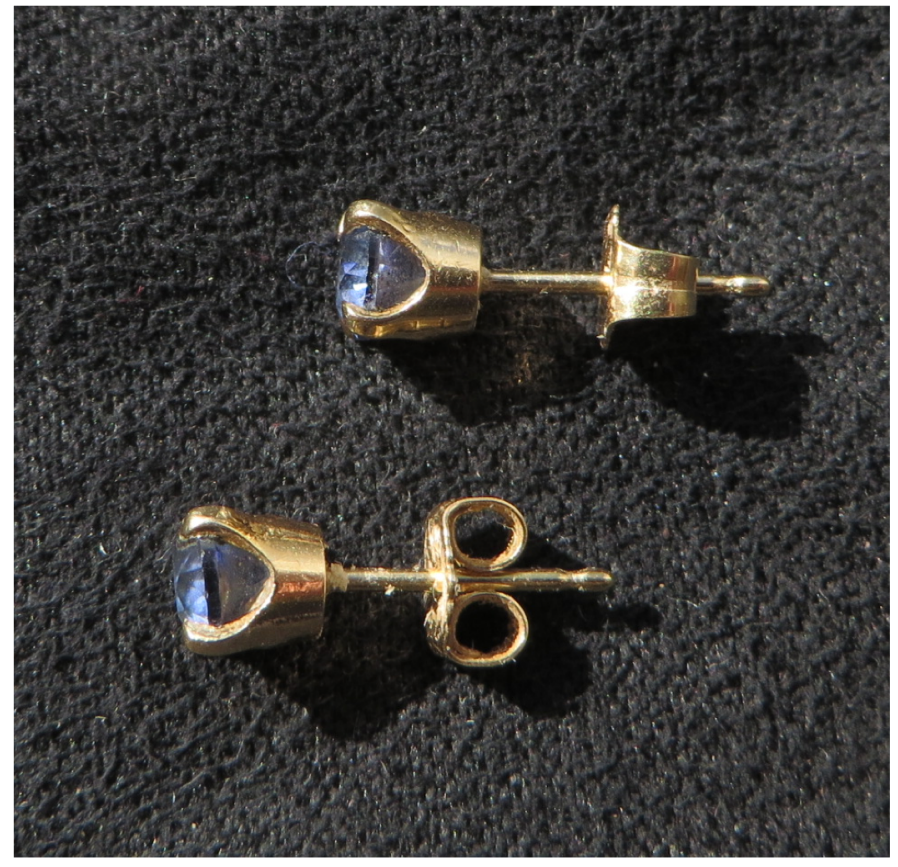

Benitoite earrings 


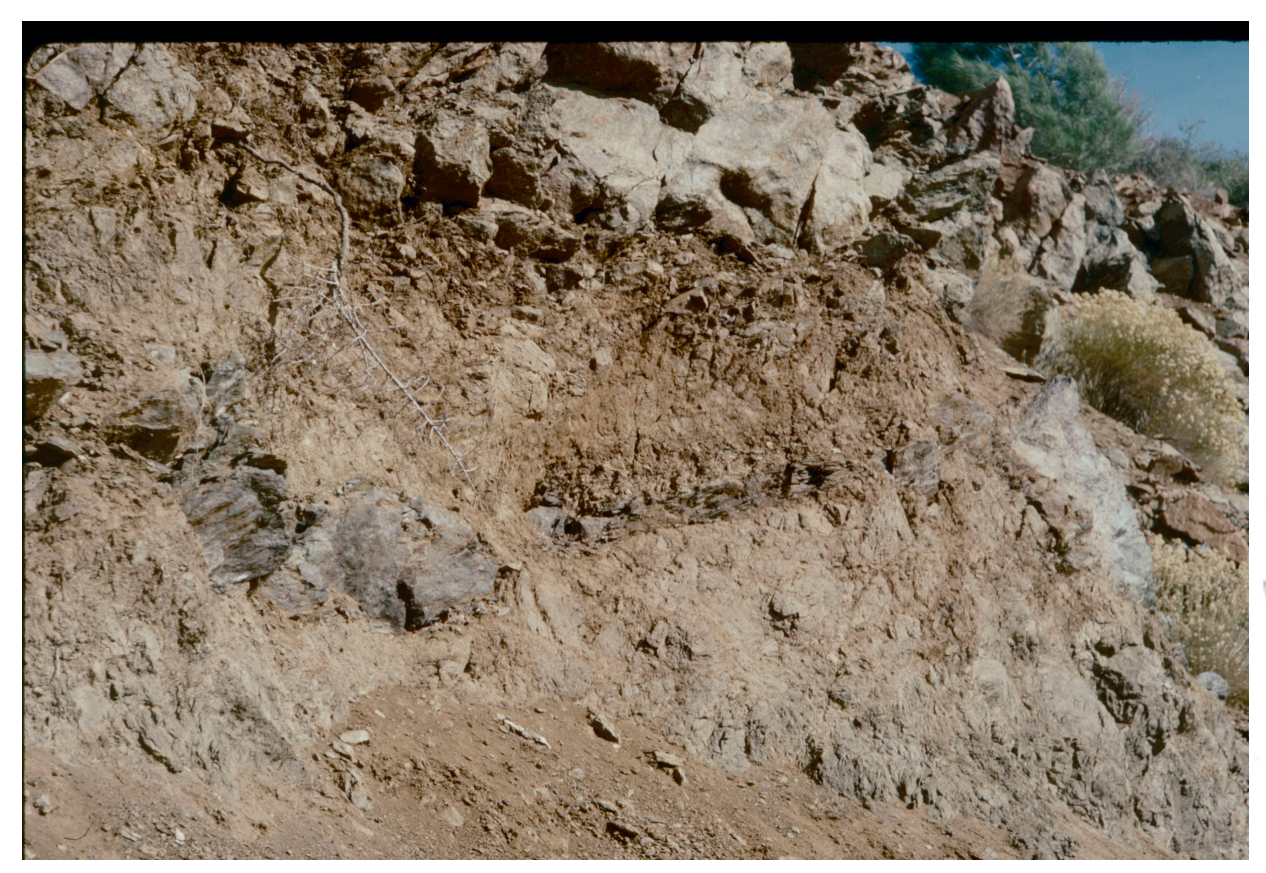

\section{The Benitoite Locality: the Gem Mine}

Figure 4.15 - Geologic Map and Cross Section of the Gem Mine
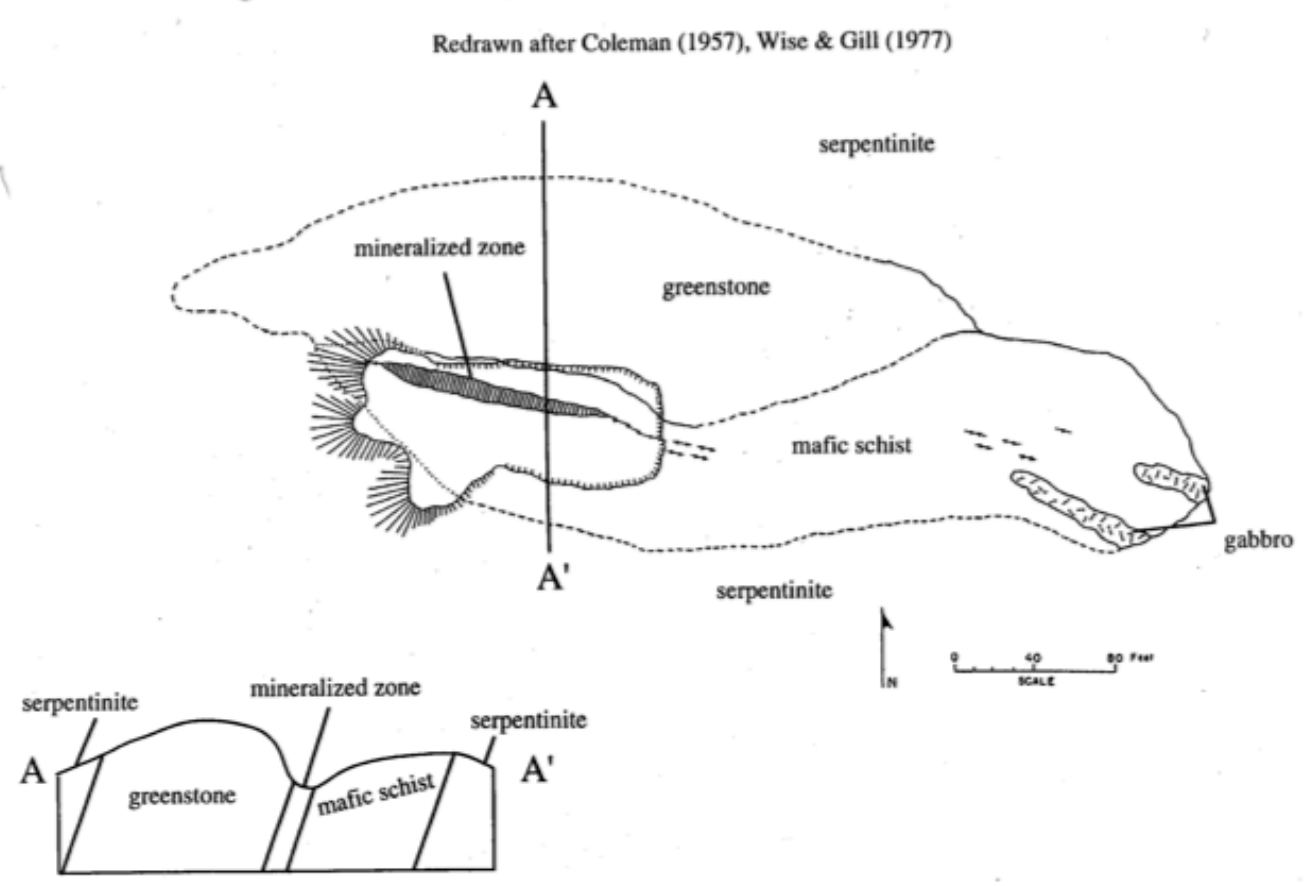


\section{Model Reactions for Formation of Benitoite at New Idria}

- barite + titanite + chlorite + glaucophane + albite $+\mathrm{H}_{2} \mathrm{O}=$

- benitoite + actinolite + natrolite $+\mathrm{SO}_{2}(\mathrm{aq})$

- Parallel reactions for neptunite, joaquinite

- Note reactions include a blueschist-greenschist transition

- All of these events occurred in the Miocene, $\sim 12 \mathrm{Ma}$

- Louderback \& Blasdale (1909) could not account for Ba \& Ti

- Coleman (1957) proposed Ti-metasomatism

- Van Baalen (1995) showed paragenesis related to reactions between tectonic blocks entrained by serpentinite

- Tiny barite crystals abundant in Franciscan Fm, titanite provides Ti

- Rare minerals are rare because they require coincidence

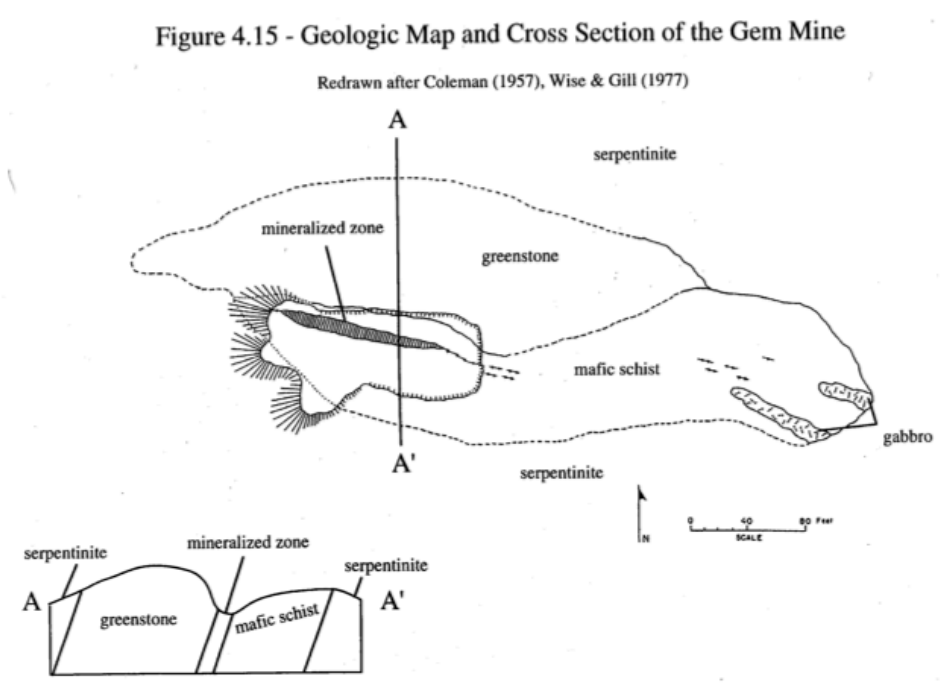




\section{Tectonic Blocks in Serpentinites}

- More common in the Jurassic Coast Range Ophiolite than in Appalachians

- Exposed serpentinites are diapirs that entrain tectonic blocks during ascent

- At New Idria see a variety of lithologies in blocks, but mainly Franciscan Fm.

- Scale ranges from meter to kilometer size

- Reactions at margins of blocks against serpentinite

- Recognition of importance of tectonic blocks due to work of Bob Coleman in 1950s.

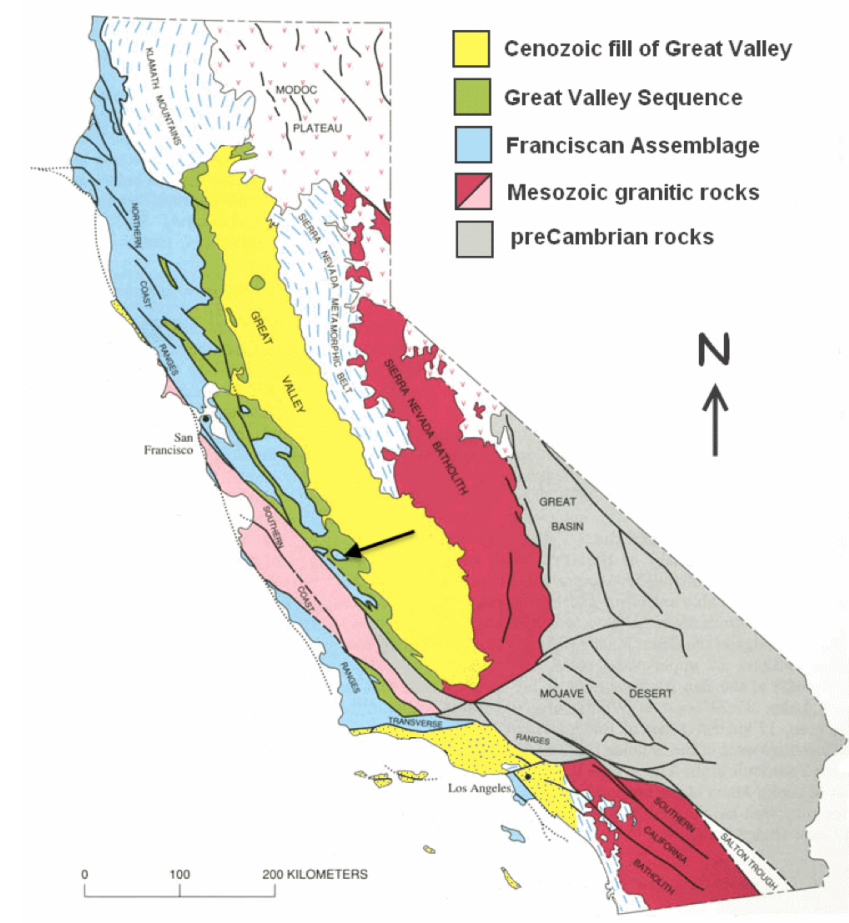




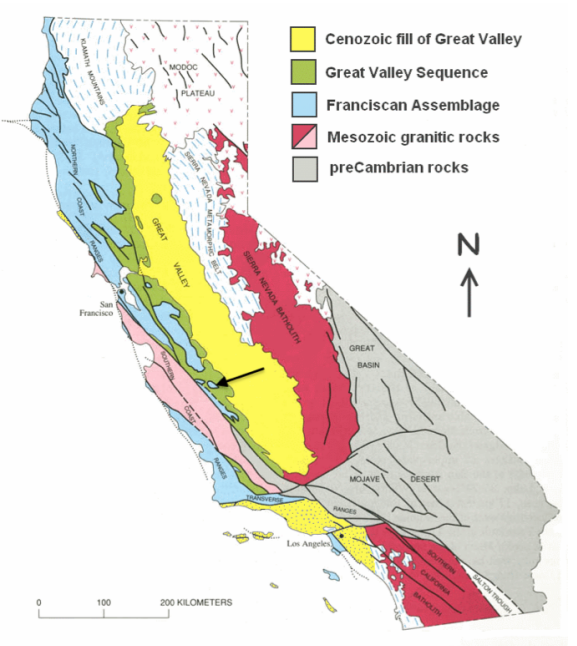

\section{New Idria Serpentinite}

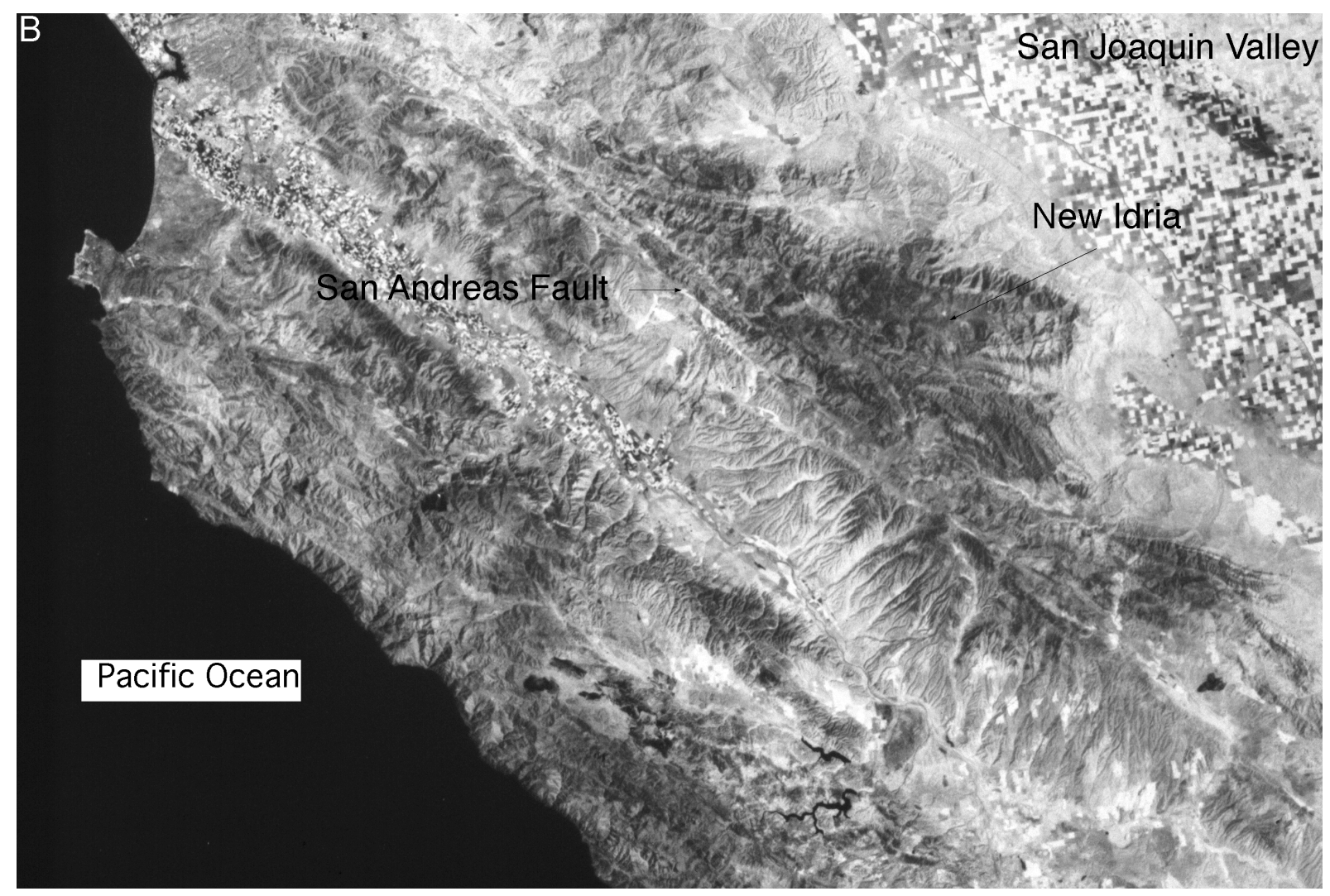




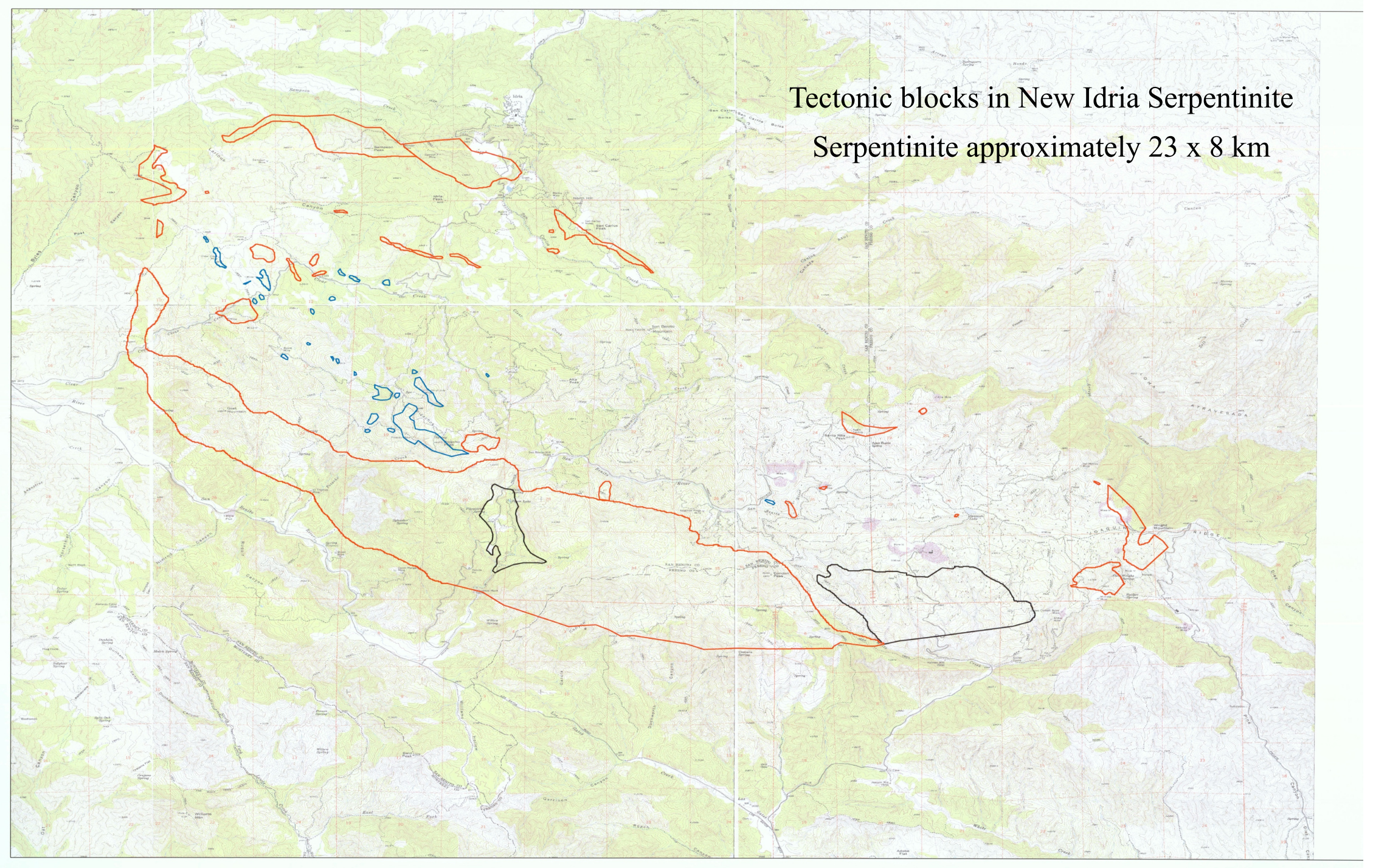




\section{Segue to amphiboles}

- Serpentinites generally not a good place to look for amphiboles, but New Idria looks like an amphibole theme park

- glaucophane \& crossite

- tremolite \& actinolite

- kaersutite (barkevikite)

- hornblende

- Amosite

- unidentified blue amphibole

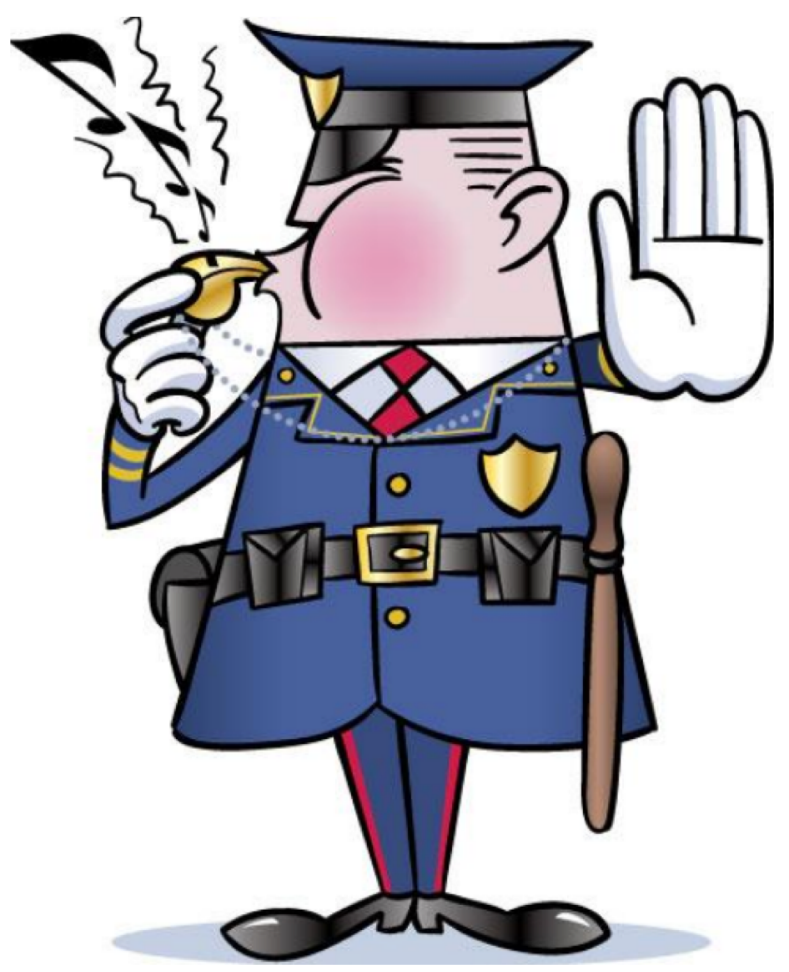


Glaucophane and Crossite
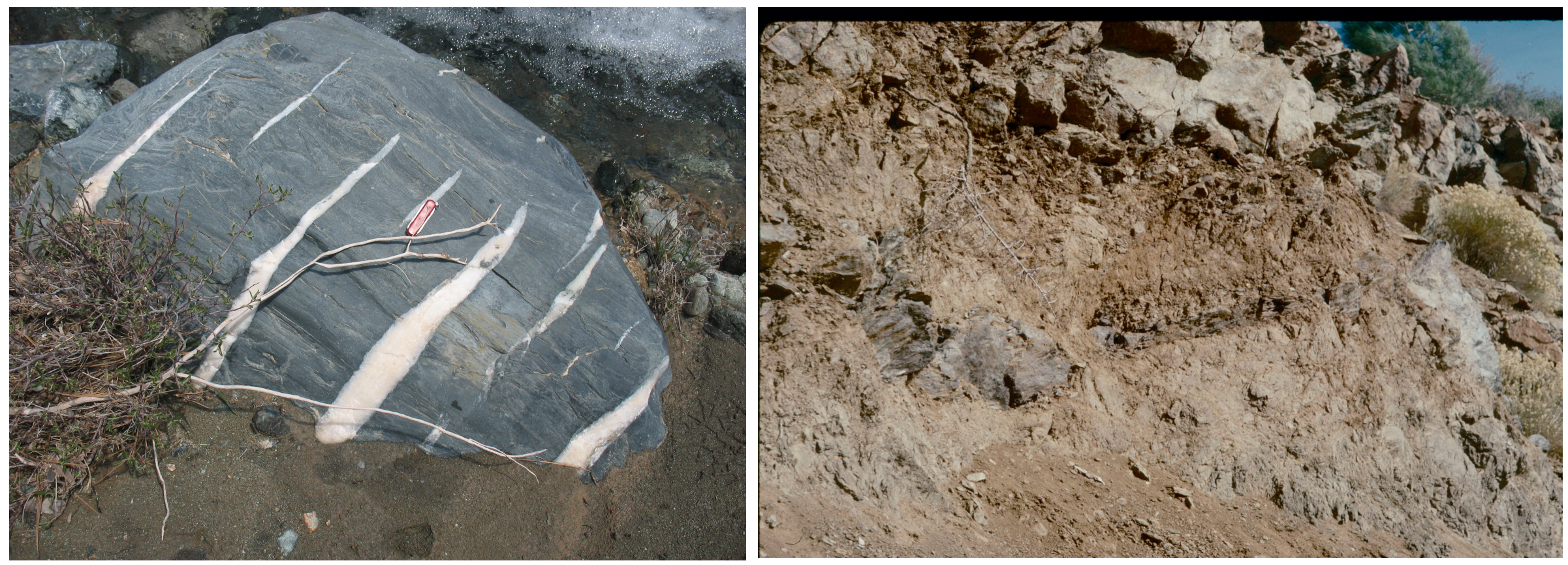


\section{Tremolite and Actinolite}

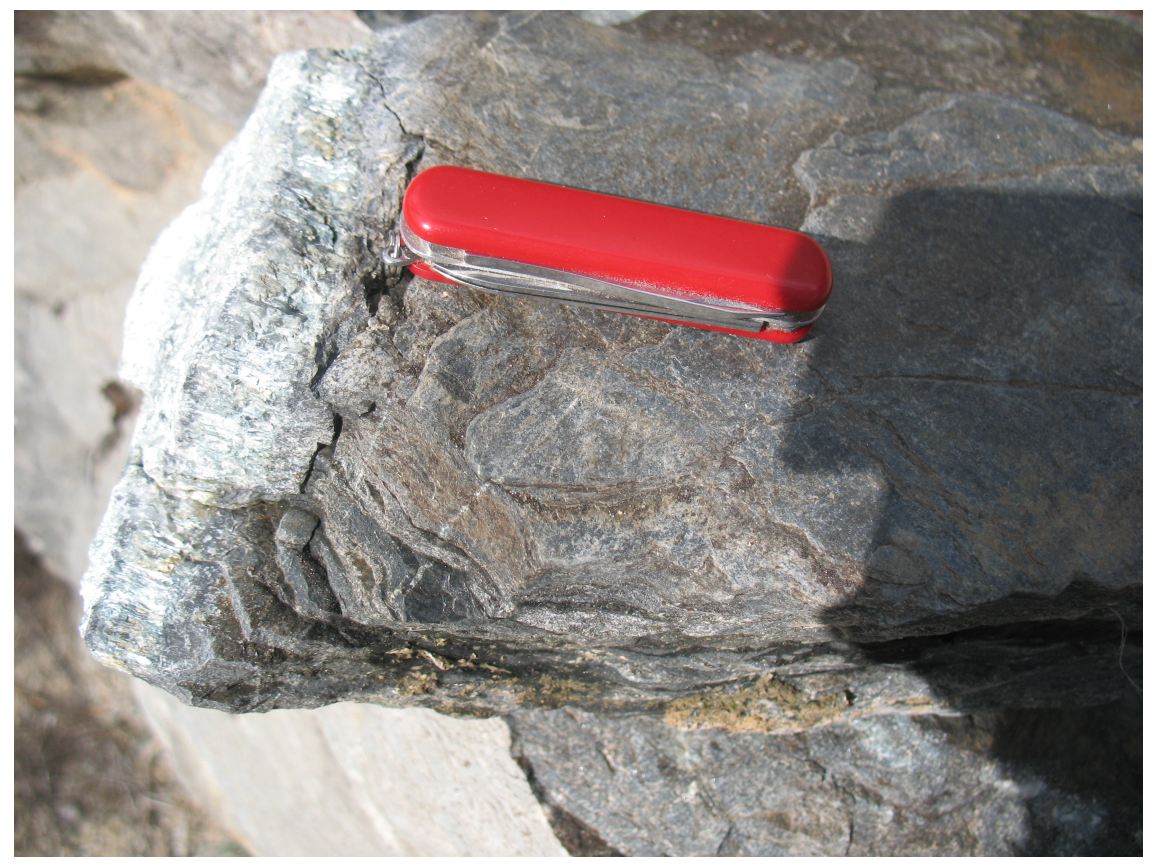

Actinolite vein in flaggy quartzite

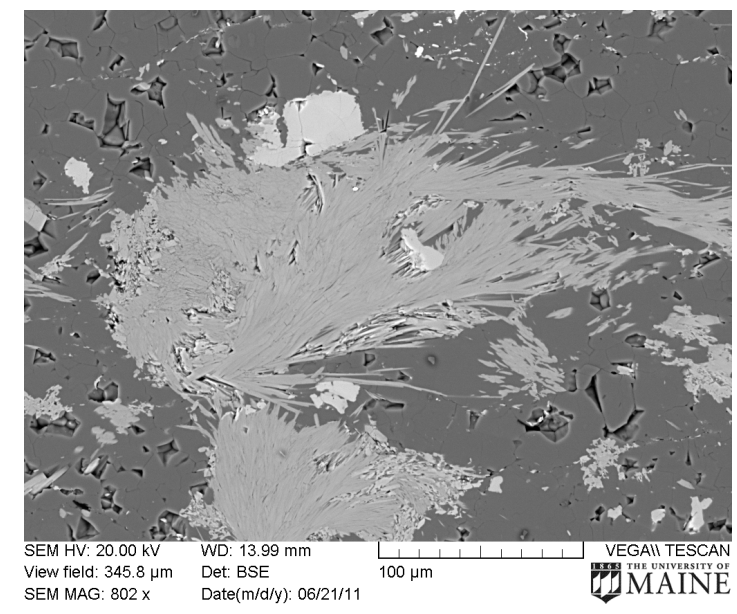

Pulverization of rock results in blades, needles and cleavage fragments in soil 
Kaersutite in an intrusive soda syenite, $12.4 \pm 0.8 \mathrm{Ma}$

Some crystals reach $18 \mathrm{~cm}$

Intrusive nature shown by metamorphic halo with prograde olivine

Coleman (1957) suggested the rich suite of Ti-bearing minerals in the serpentinite was due to Ti metasomatism from this intrusion.

Van Baalen (1993) showed this was not feasible due to the low solubility of Ti complexes.

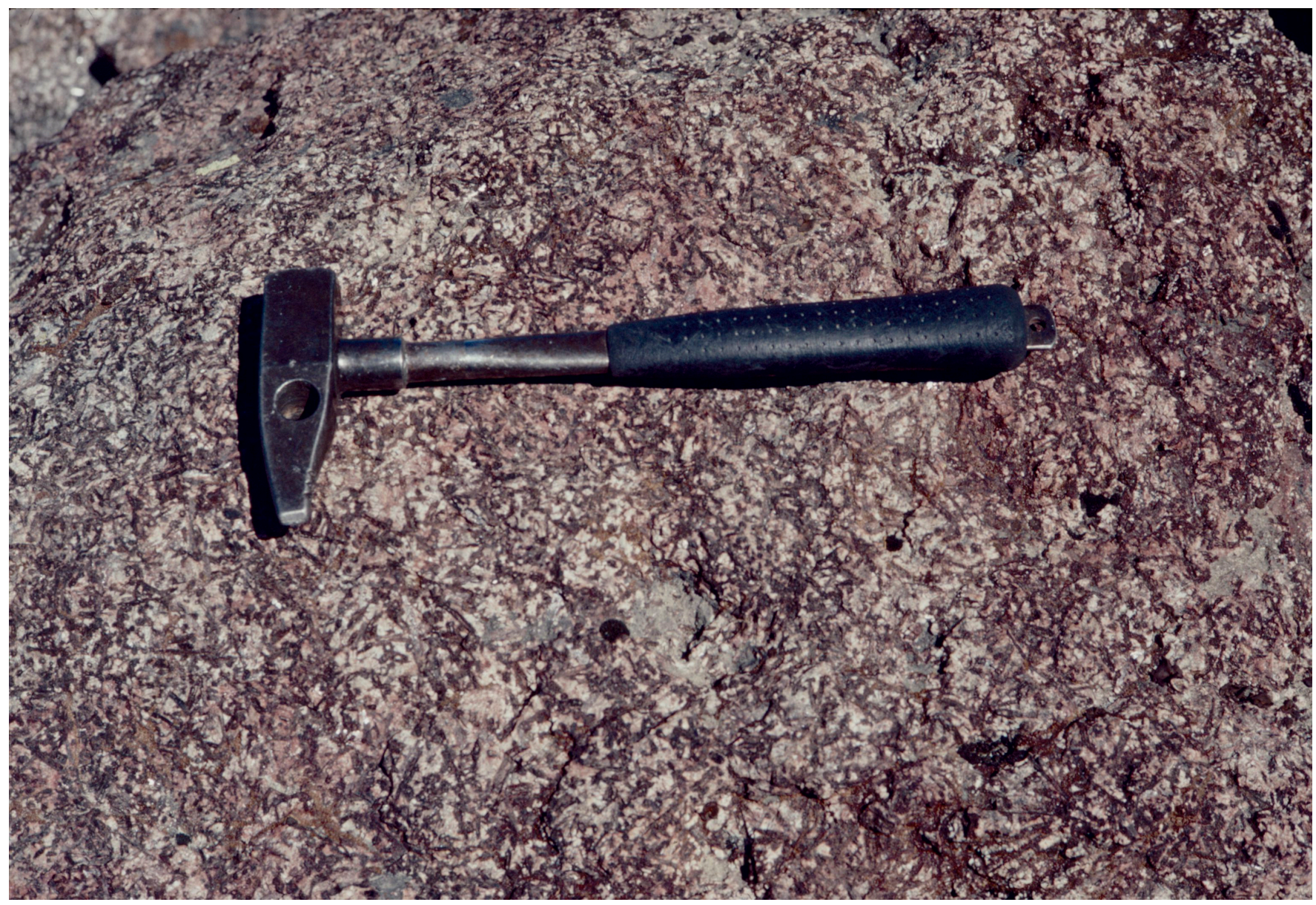




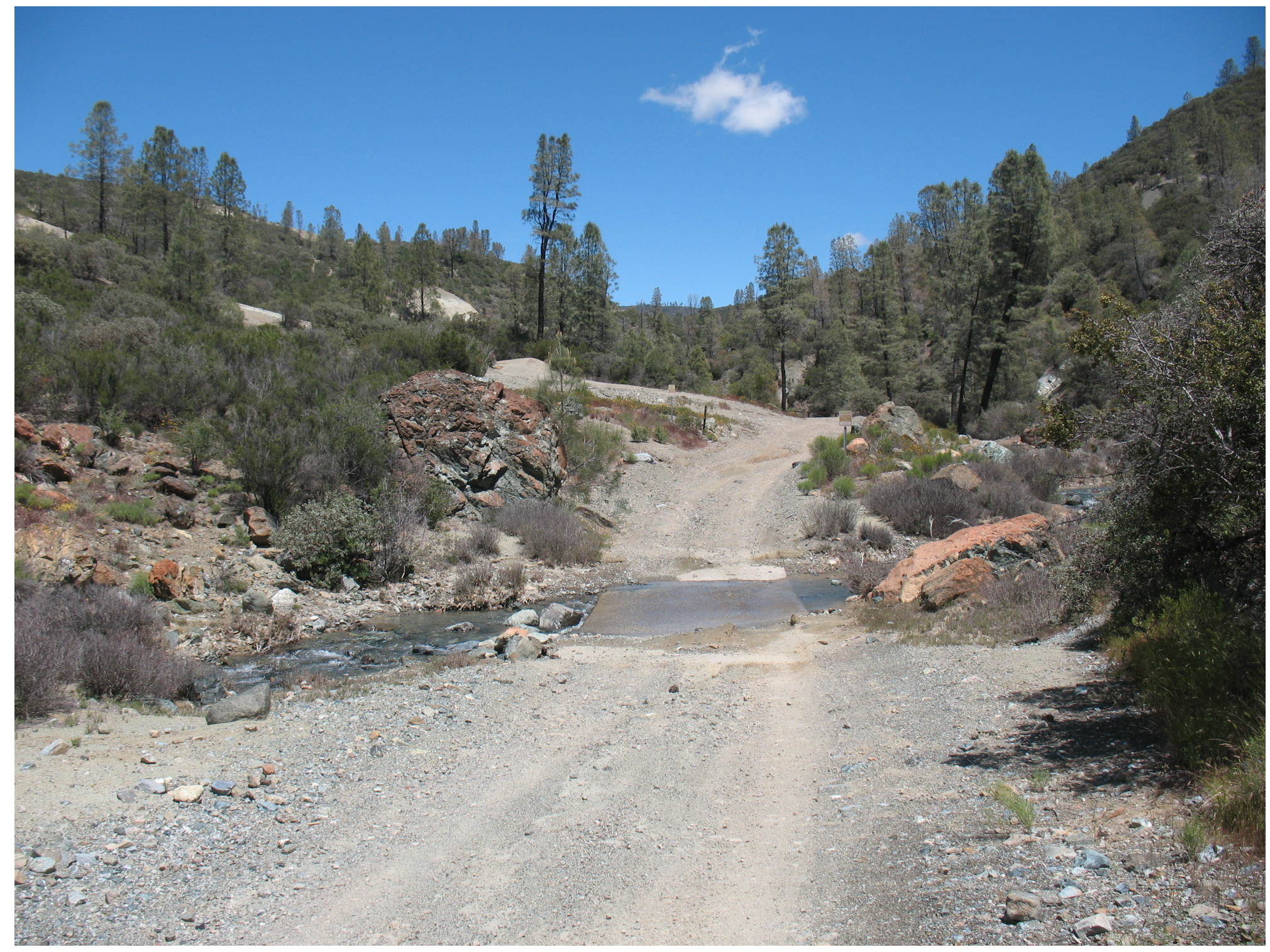

Hornblende derived from hornblende granite used as road metal at stream crossings in road network - pulverized by vehicle traffic 


\section{Amosite from mining artifacts}
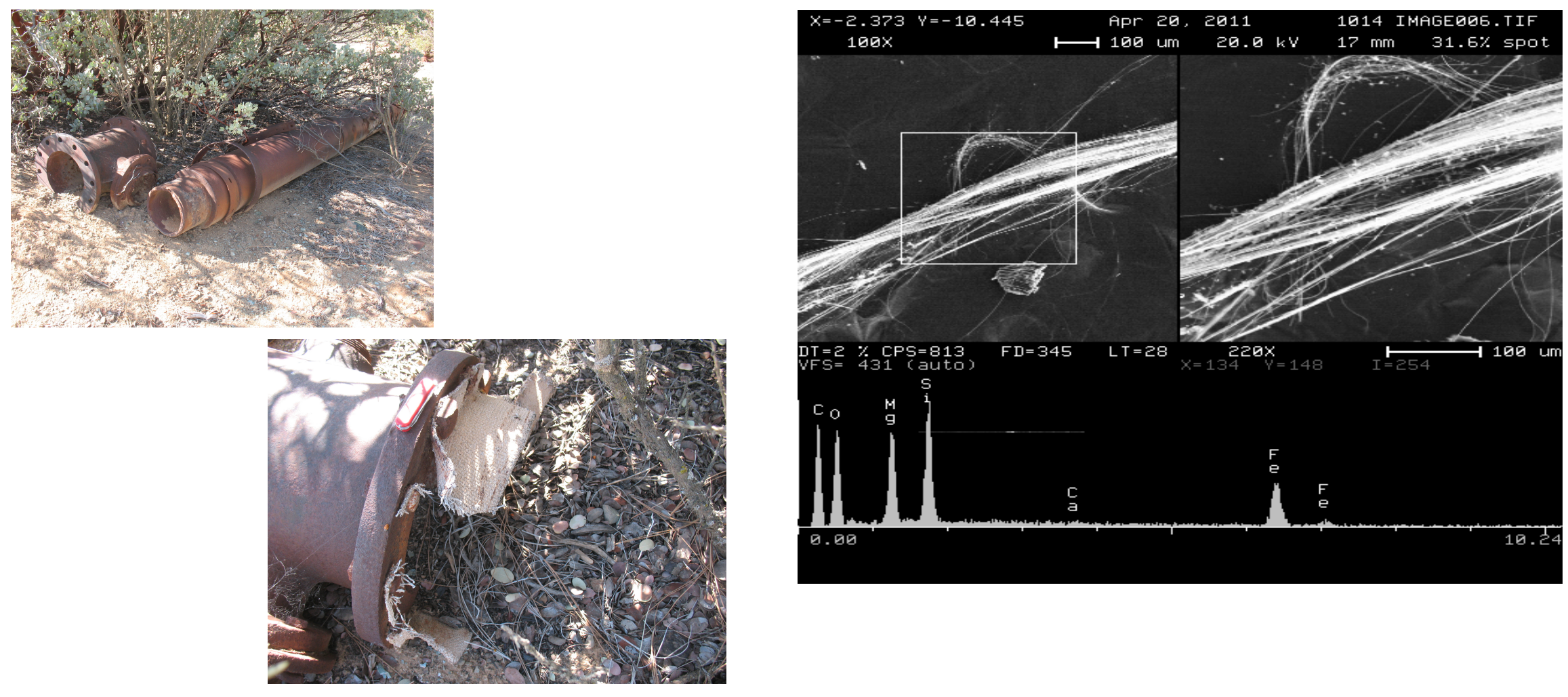
Figure 3.11 - Condensed Space for Sodic-Calcic Amphiboles

An unnamed blue amphibole was found in veins crosscutting antigorite, near the contact with a large tectonic block of Franciscan Fm.

Composition lies in the tilted plane shown to the right, within Laird Space, projected along the $\mathrm{FeMg}_{-1}$ exchange vector

Origin of blue amphibole is problematic

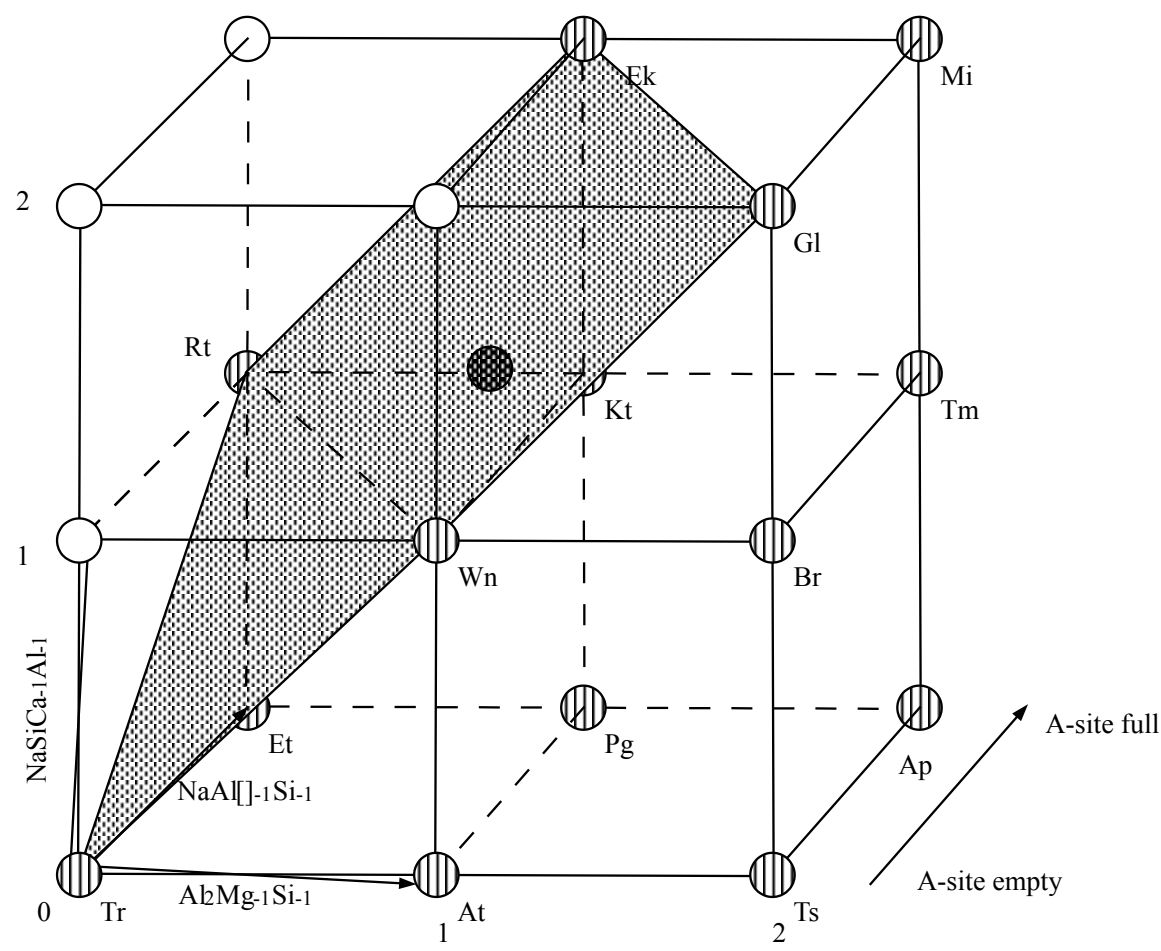



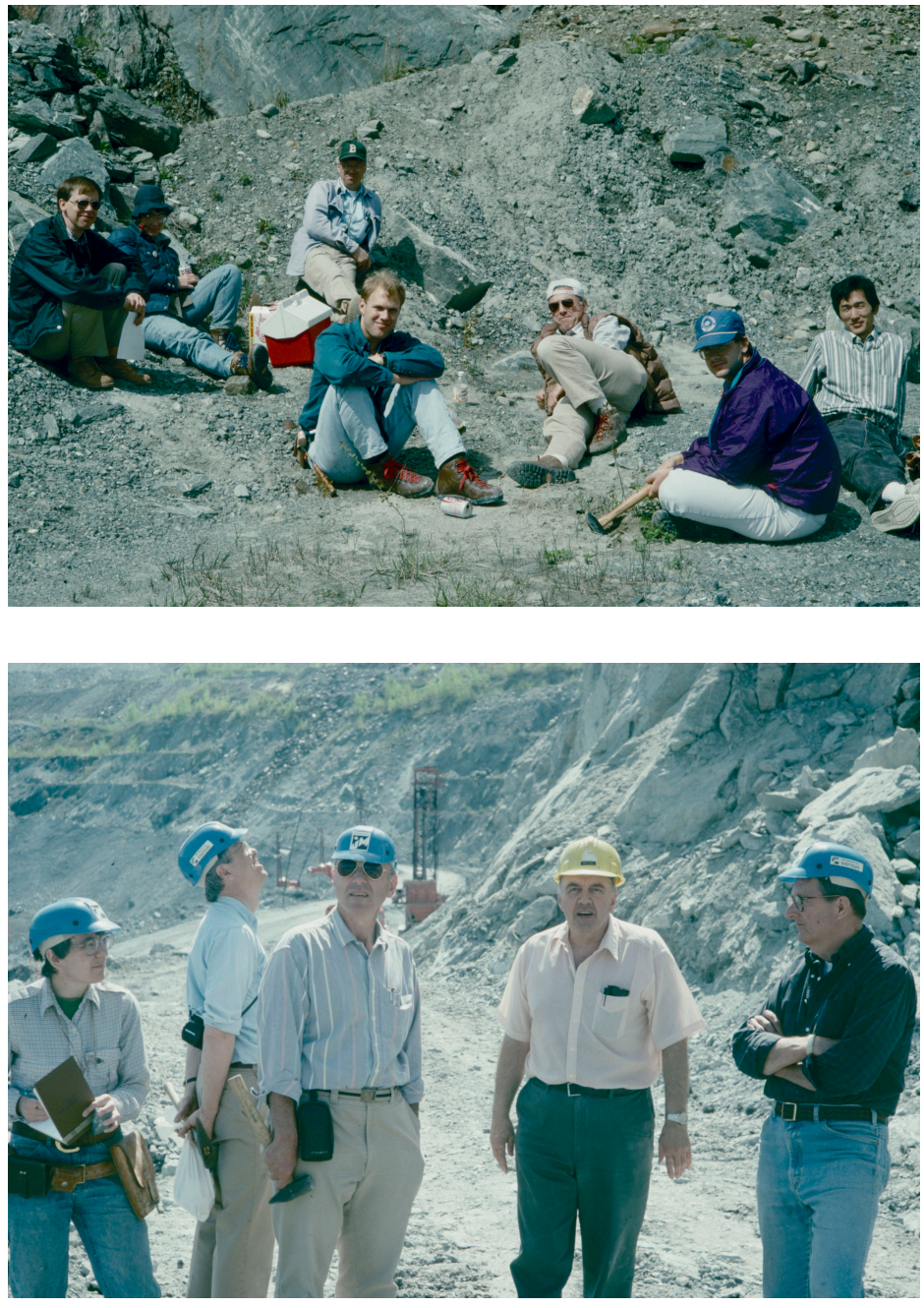

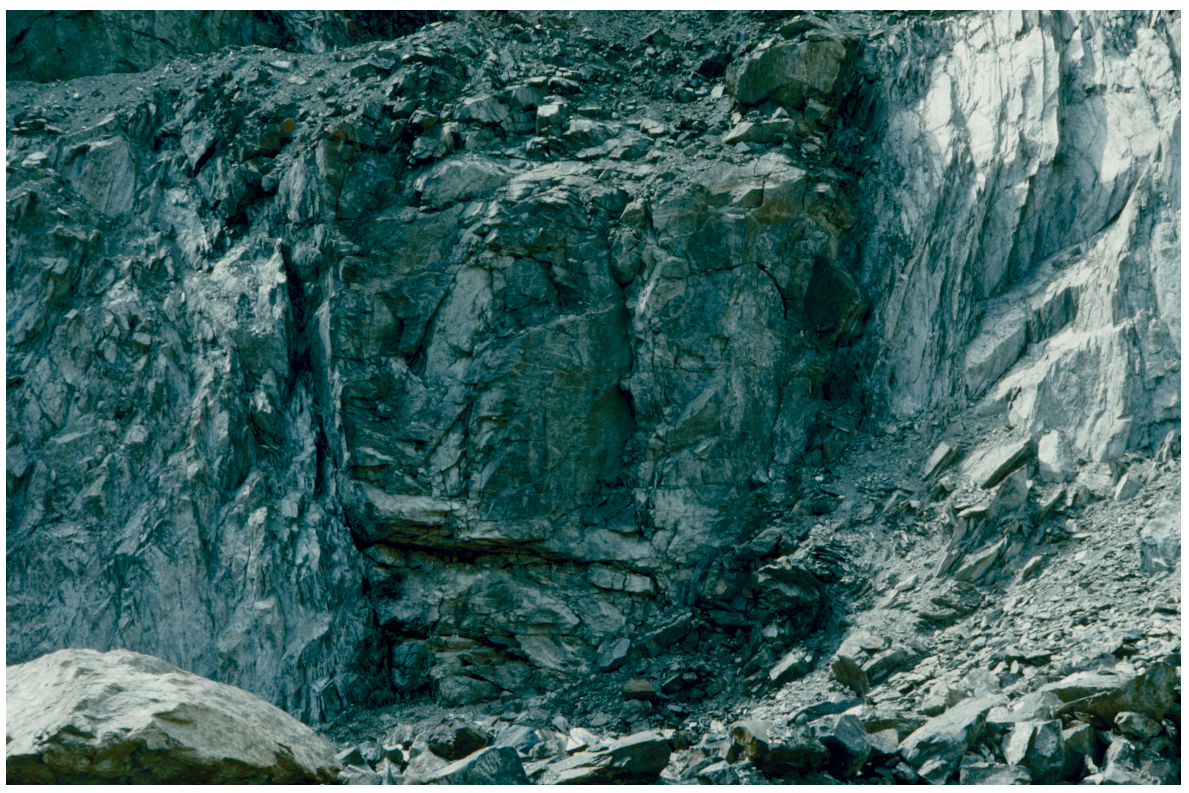

Returning to the Appalachians,

Belvidere Mt. serpentinite does contain tremolite, as an accessory mineral in the rodingite at the Lowell Quarry 


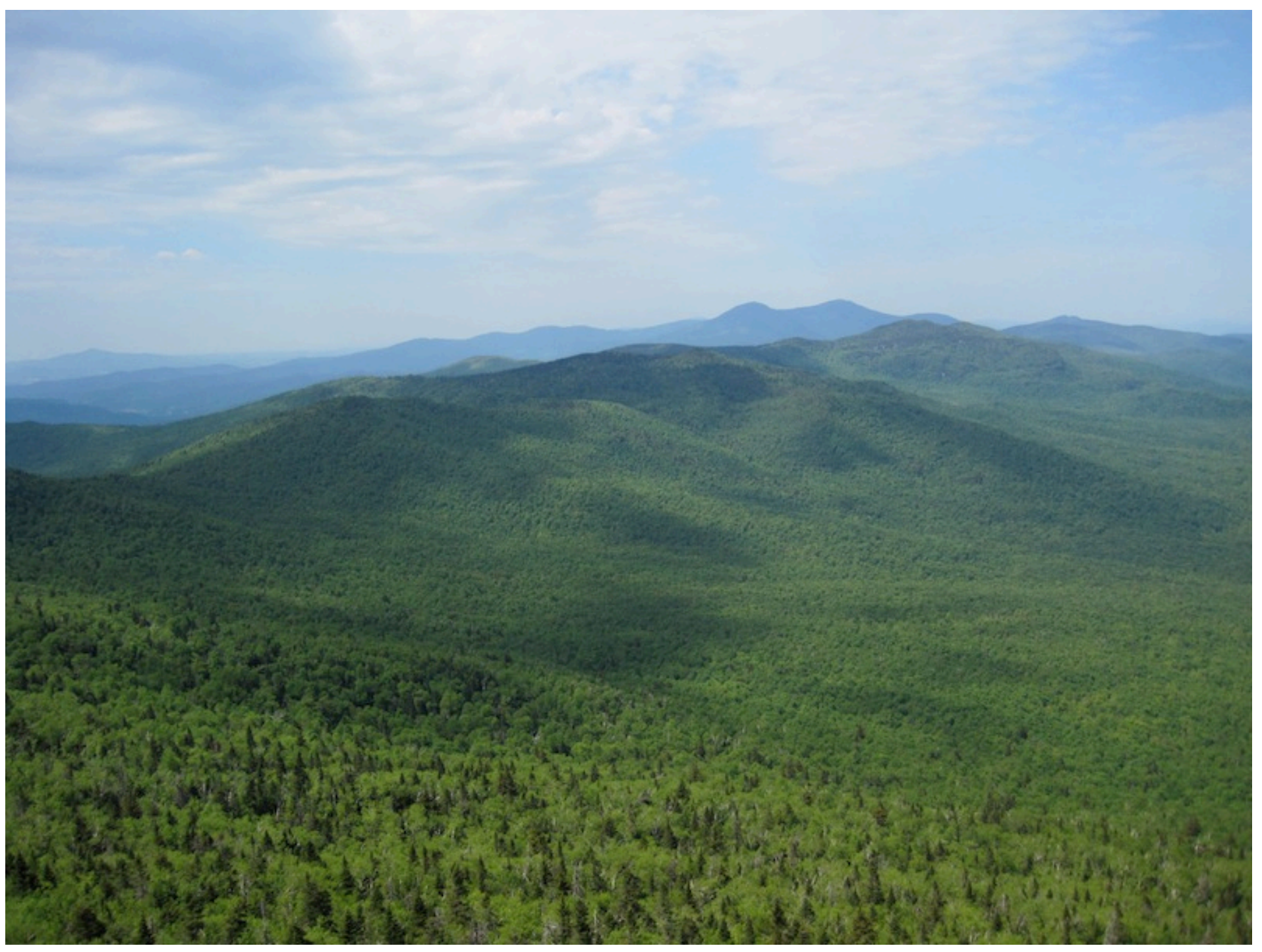

View to the north from summit of Belvidere Mt., Vermont, looking towards Tillotson Peak and Hazens Notch, in Laird Country 
Thanks, Jo

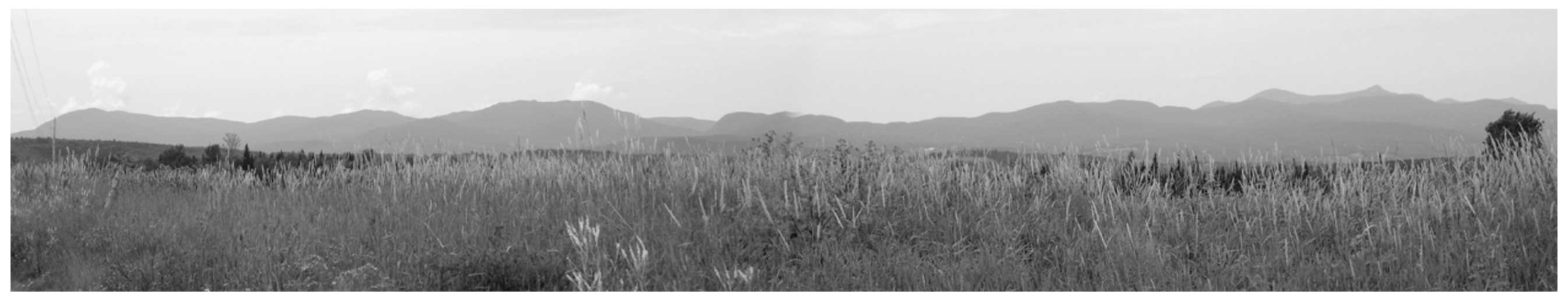

